\title{
Inhibition of ERAD synergizes with FTS to eradicate pancreatic cancer cells
}

\author{
Rong Du'1,2,3, Delaney K. Sullivan ${ }^{4}$, Nancy G. Azizian ${ }^{1,2}$, Yuanhui Liu ${ }^{1,2}$ and Yulin Li $i^{1,2^{*}}$
}

\begin{abstract}
Background: Pancreatic ductal adenocarcinoma (PDAC), one of the most lethal cancers, is driven by oncogenic KRAS mutations. Farnesyl thiosalicylic acid (FTS), also known as salirasib, is a RAS inhibitor that selectively dislodges active RAS proteins from cell membrane, inhibiting downstream signaling. FTS has demonstrated limited therapeutic efficacy in PDAC patients despite being well tolerated.

Methods: To improve the efficacy of FTS in PDAC, we performed a genome-wide CRISPR synthetic lethality screen to identify genetic targets that synergize with FTS treatment. Among the top candidates, multiple genes in the endoplasmic reticulum-associated protein degradation (ERAD) pathway were identified. The role of ERAD inhibition in enhancing the therapeutic efficacy of FTS was further investigated in pancreatic cancer cells using pharmaceutical and genetic approaches.

Results: In murine and human PDAC cells, FTS induced unfolded protein response (UPR), which was further augmented upon treatment with a chemical inhibitor of ERAD, Eeyarestatin I (Eerl). Combined treatment with FTS and Eerl significantly upregulated the expression of UPR marker genes and induced apoptosis in pancreatic cancer cells. Furthermore, CRISPRbased genetic ablation of the key ERAD components, HRD1 and SEL1L, sensitized PDAC cells to FTS treatment.

Conclusion: Our study reveals a critical role for ERAD in therapeutic response of FTS and points to the modulation of UPR as a novel approach to improve the efficacy of FTS in PDAC treatment.

Keywords: Pancreatic ductal adenocarcinoma (PDAC), Clusters of regularly interspaced short palindromic repeats (CRISPR), Farnesyl thiosalicylic acid (FTS), Salirasib, Endoplasmic reticulum-associated protein degradation (ERAD), Unfolded protein response (UPR)
\end{abstract}

\section{Background}

The most prevalent pancreatic malignancy, pancreatic ductal adenocarcinoma (PDAC), is among the most aggressive cancers, with a dismal prognosis, and highly refractory to most treatment options [1]. KRAS mutations have been identified as the oncogenic driver in PDAC [2]. RAS is a membrane bound GTPase that functions as a molecular switch, cycling between active GTP-bound state facilitated by guanine nucleotide exchange factors,

\footnotetext{
* Correspondence: yli@houstonmethodist.org

${ }^{1}$ Center for Immunotherapy Research, Houston Methodist Research Institute, Houston, TX 77030, USA

${ }^{2}$ Department of Medicine, Weill Cornell Medical College, New York, NY 10065, USA

Full list of author information is available at the end of the article
}

and inactive GDP-bound state regulated by GTPaseactivating proteins [3]. Upon activation of cell-surface receptors, RAS switches to the GTP-bound state to recruit and activate cytoplasmic effectors involved in a variety of signaling networks [4]. Oncogenic mutations impair the ability of KRAS to hydrolyze GTP, and lock the oncoprotein in its constitutively active GTP-bound state, leading to hyperactivation of effector signaling pathways driving tumorigenesis [5].

Given its critical function as an oncogenic driver, extensive efforts have been devoted to the development of specific RAS inhibitors [6-8]. However, the lack of binding sites for small chemical inhibitors on the RAS protein surface has hindered the efforts to directly target RAS. Furthermore, drugging RAS through the use of

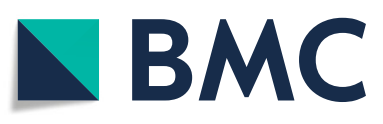

(c) The Author(s). 2021 Open Access This article is licensed under a Creative Commons Attribution 4.0 International License, which permits use, sharing, adaptation, distribution and reproduction in any medium or format, as long as you give appropriate credit to the original author(s) and the source, provide a link to the Creative Commons licence, and indicate if changes were made. The images or other third party material in this article are included in the article's Creative Commons licence, unless indicated otherwise in a credit line to the material. If material is not included in the article's Creative Commons licence and your intended use is not permitted by statutory regulation or exceeds the permitted use, you will need to obtain permission directly from the copyright holder. To view a copy of this licence, visit http://creativecommons.org/licenses/by/4.0/ The Creative Commons Public Domain Dedication waiver (http://creativecommons.org/publicdomain/zero/1.0/) applies to the data made available in this article, unless otherwise stated in a credit line to the data. 
GTP antagonists has not been feasible due to the extremely high affinity (picomolar) to GTP and GTP abundance (millimolar) in cells. Failure to develop clinicallyapproved RAS inhibitors has prompted the perception that RAS proteins are "undruggable" [9]. In recent years, exciting progresses have been made in directly targeting the rare KRAS ${ }^{\mathrm{G} 12 \mathrm{C}}$ mutant [10-14], but not the more prevalent mutations, such as G12D, G12V, and G12R.

RAS proteins undergo a series of post-translational modifications related to their biological functions such as acetylation, ubiquitination, phosphorylation, and farnesylation among many [15]. Localization of KRAS on plasma membrane is crucial to downstream signal transduction, and farnesylation at $\mathrm{C}$-terminal cysteine (CAAX motif) is essential for its localization and activation [16]. Farnesyl thiosalicylic acid (FTS), also known as salirasib, was developed as a pan-RAS inhibitor [17]. FTS mimics the C-terminal farnesyl cysteine carboxymethyl ester of all RAS isoforms and selectively dislodges active RAS proteins from cell membrane, inhibiting their biological functions [18]. Promising findings in preclinical models have prompted several clinical trials in leukemia, lung, and pancreatic cancers $[19,20]$. However, FTS alone has shown only modest activity in patients despite minimal side effects [21-23], suggesting further efforts to develop FTS for the treatment of PDAC should be focused on drug combinations to enhance the therapeutic efficacy.

Combinatorial strategies, such as coupled targeting of KRAS and mitochondrial respiration pathways [24], or concomitant suppression of ERK and autophagy [25], have been proposed for PDAC treatment with the goal of achieving better therapeutic responses. The concept of synthetic lethality has been widely exploited in the development of targeted therapeutics and combination therapies. The conceptual framework posits that, two perturbations are considered synthetic lethal if either one acting alone is compatible with viability, but when combined, will lead to cell death [26, 27]. Functional genetic approaches, such as RNAi and CRISPR screens, have been employed to discover novel genetic targets of synthetic lethality and identify combination therapies $[28,29]$. In particular, CRISPR-Cas9 genome-wide screens have superior efficiency and increased specificity $[30,31]$. We, therefore, set out to identify genetic targets that enhance FTS efficacy in PDAC by performing a genome-wide CRISPR synthetic lethality screen. Among the top candidates, genes related to endoplasmic reticulum-associated protein degradation (ERAD) were highly enriched. Moreover, we showed that FTS induced unfolded protein response (UPR) in murine and human PDAC cells, which was further enhanced by suppression of ERAD to induce apoptosis.

\section{Methods}

Cell lines and chemical reagents

4292 murine PDAC cell line, expressing mutant KRAS $^{\text {G12D }}$ under the control of the Tet-ON system, and p53 ${ }^{\mathrm{R} 172 \mathrm{H}}$, was a generous gift from Dr. Marina Pasca di Magliano at the University of Michigan [32, 33]. 4292 cells were cultured in RPMI 1640 supplemented with $10 \%$ FBS, $1 \%$ penicillin/streptomycin, and $1 \mu \mathrm{g} / \mathrm{ml}$ doxycycline. Human PDAC cell lines, PANC-1 and MIA $\mathrm{PaCa}-2$, were purchased from ATCC and cultured in DMEM supplemented with 10\% FBS and 1\% penicillin/ streptomycin. FTS, Eeyarestatin I, and GSK2606414 were purchased from Cayman Chemical.

Pooled "synthetic lethal" CRISPR screen and data analysis The CRISPR library screen was performed following published protocols [34]. The pooled mouse CRISPR lentiviral library containing 78,637 gRNAs targeting 19,674 genes was obtained from Addgene (\#73633-LV, lentiviral prep), and the screen was performed in duplicate with two independent viral infections. Briefly, 4292 cells with stable Cas9 expression were infected at low viral titers so that approximately $10 \%$ of the cells were infected. The infected cells were selected with puromycin $(1 \mu \mathrm{g} / \mathrm{ml})$ for 2 days. The experimental pool was treated with $100 \mu \mathrm{M}$ FTS for 12 days. Both experimental and control pools were passaged every 3 days with at least 50 million cells per pool to ensure 500-1000X coverage. Following FTS treatment, the gRNA libraries in the cell populations were isolated by PCR amplification and identified by Hiseq. Computational analysis of the libraries was performed using MAGeCK (version 0.5.9.2). First, cutadapt (version 2.6) was used to trim primer and other technical sequences from pairedend FASTQ files with the specified options: -j 0 --maximum-length 30 --pair-filter = both -e 0.3 -g GCTTTATA TATCTTGTGGAAAGGACGAAACACC...GTTTTAGA GCTAGAAATAGCAAGTTAAAATAAGGCTAGTCCG TTATCAACTTGAAAAAGT -G CCGACTCGGTGCCA CTTTTTCAAGTTGATAACGGACTAGCCTTATTTT AACTTGCTATTTCTAGCTCTAAAAC...GGTGTTTC GTCCTTTCCACAAGATATATAAAGC. Second, the command, mageck count, was run under default options with the trimmed paired-end FASTQ files supplied in the arguments --fastq and --fastq- 2 to collect read counts. Finally, the command, mageck mle, was run, specifying an unpaired design for the biological duplicates, 10 permutation rounds, 2500 genes for mean-variance modeling, the --remove-outliers option, median normalization, FDR $p$ value adjustment, and a list of the 1000 control sgRNAs in the library supplied to the --control-sgrna option. The resulting beta scores and FDR-adjusted permutation $p$ values were used in downstream analysis. All samples had a mapping rate of $89-90.2 \%$, gini index (a measure of the evenness of sgRNA read counts) of 0.066-0.072, and 384- 
502 zero-count sgRNAs. Enrichr was used for gene ontology (GO) analysis of genes with a negative beta score and an FDR $<0.05 \quad(n=488$ genes $)$ [35]. The visualization tool, Clustergrammer, was used to graphically depict the top $20 \mathrm{GO}$ terms (as ranked by $p$ value) and their associated genes.

\section{IC50 determination and cell viability assay}

Cells were seeded at the following concentrations: 4000 cells for 4292, 16,000 cells for PANC-1, 8000 cells for MIA PaCa-2 per well in 24-well plates. Drugs were added the next day in triplicates. Following 5 days of drug treatment, cell viability was assessed using the CellTiter-Glo 2.0 Cell Viability Assay (Promega) according to the manufacturer's instructions. Data analysis and calculation of the half-maximal inhibitory concentration (IC50) were carried out using GraphPad Prism 8 (GraphPad).

\section{Western blot analysis}

Cells were lysed on ice in CelLytic MT Cell Lysis Reagent (Sigma) supplemented with protease and phosphatase inhibitors. Protein concentration was determined with Pierce BCA Protein Assay Kit (Thermo Fisher). Protein lysates were resolved on SDS-PAGE gels and transferred to PVDF membranes [36]. The following antibodies were used for the western blot analysis: phospho-eIF2 $\alpha$ (\#9721, 1:1000), eIF2 $\alpha$ (\#9722, 1:1000), ATF4 (\#11815, 1:1000), BIM (\#2819, 1:1000), SYVN1 (\#14773, 1:1000) from Cell Signaling Technology; phospho-PERK (Thr980) (MA515033, 1:1000, Thermo Fisher); SEL1L (S3699, 1:1000, Sigma); $\beta$-tubulin (10094-1-AP, 1:5000, Proteintech).

\section{RNA extraction and quantitative real-time PCR}

RNA was extracted with the RNeasy Mini Kit (Qiagen). cDNA was synthesized using the Verso cDNA Synthesis Kit (Thermo Scientific) according to the manufacturer's instructions. qPCR analysis was performed on a 7500 Real-Time PCR System using SYBR Green (Applied Biosystems). Primer sequences are available in Supplementary Table 3. Transcripts were normalized to human GAPDH or mouse UBC, and relative gene expression was determined with ddCt method as previously reported [36].

\section{Flow cytometry}

PE Annexin-V Apoptosis Detection Kit (BD Biosciences) was used to detect apoptosis following manufacturer's instruction [36]. Briefly, cells were suspended in $100 \mu \mathrm{l}$ of $1 \mathrm{X}$ binding buffer and mixed with $5 \mu \mathrm{l}$ of PEconjugated annexin- $\mathrm{V}$ and 7-AAD respectively, followed by incubation at room temperature for $15 \mathrm{~min}$ in the dark. The stained cells were analyzed using a BD FACS Fortessa flow cytometer (BD Bioscience). All flow cytometric data were analyzed with FlowJo software (Tree Star).

\section{CRISPR sgRNA generation, transfection and single-cell sorting}

For construction of sgRNA-expressing vectors, DNA oligonucleotides were annealed and cloned in BbsI-digested pSpCas9(BB)-2A-GFP (PX458) plasmid (Addgene \#48138). Target sgRNA oligonucleotide sequences are listed in Supplementary Table 4. MIA PaCa-2 cells were seeded in 6well plates at 0.5 million/well the day before transfection. PX458 empty vector or pooled sgRNA plasmids $(2.5 \mu \mathrm{g} /$ well) were transfected into MIA PaCa-2 cells using lipofectamine 3000 (Invitrogen). Three days after transfection, cells were collected and GFP-positive cells were sorted in 96-well plate using a BD FACS Fortessa flow cytometer (BD Bioscience).

\section{Retrovirus packaging and transduction}

Retroviral vectors for the expression of fluorescent markers were combined with pCL-10A1 retrovirus packaging vector at 1:1 ratio and transfected into HEK293FT cells using lipofectamine 3000 transfection reagent (Invitrogen). Supernatants containing the viral particles were collected at $48 \mathrm{~h}$ post-transfection and passed through a sterile $0.45 \mu \mathrm{m}$ syringe filter (VWR). Wild type, SYVN1 KO1, and SEL1L KO1 cells were infected by viral supernatant supplemented with $6 \mu \mathrm{g} / \mathrm{ml}$ polybrene in 6 -well plate by centrifugation at $1000 \mathrm{~g}$ for $90 \mathrm{~min}$. Infected cells were selected by growing in DMEM medium containing $3 \mu \mathrm{g} / \mathrm{ml}$ puromycin for 2 days.

\section{Multicolor competition assay}

pBabe puro IRES-mCherry (Addgene \#128038) and pBabe puro IRES-EGFP (Addgene \#128037) were used for labeling. MIA PaCa-2-derived single clones labeled with mCherry (wild type) and GFP (SYVN1 KO1 or SEL1L KO1) were mixed at 1:1 ratio. Mixed cell populations were seeded in T25 flasks at 0.2 million cells per cell line. One day after seeding (D0) wells were imaged with Leica DMi8 with a $5 \mathrm{X}$ objective and mCherry and GFP positive cells were counted from three different images. Cells were treated with DMSO or FTS for 2 weeks. Relative cell fitness was calculated from the percentage of GFP-positive cells normalized to the D0 value.

\section{Statistical analysis}

Cell viability and apoptotic cell percentage among different treatment groups were analyzed using ANOVA with Tukey's test. Other viability assays and transcript levels were analyzed using two-tailed student's t test. Statistical significance of multicolor competition assay was assessed using unpaired two-sample t test. Results were presented as mean \pm standard deviation (SD). 


\section{Results}

\section{CRISPR screen identifies ERAD as a cellular process modulating FTS efficacy}

To discover potential genetic targets that modify sensitivity to FTS, we performed a genome-wide CRISPR library screen utilizing a murine pooled sgRNA library [37]. Cas 9 nuclease was introduced in the murine PDAC cell line 4292 by lentiviral infection, followed by the sgRNA library, which contains 78,637 gRNAs targeting 19,674 genes. Following puromycin selection, the cell population containing the gRNA library was further expanded and split into control and FTS pools. FTS pool was treated with the drug for 12 days, while the control pool was maintained in culture. At the end of the treatment, genomic DNA from both pools was collected for PCR amplification of sgRNA libraries and further analysis of sgRNA frequency by deep-sequencing (Fig. 1a). A "beta score" was calculated for each gene to measure the degree of selection using MAGeCK's maximum likelihood estimation algorithm (Supplementary Table 1) [38]. The beta score quantifies the effect size with negative values suggesting sgRNA depletion and positive values suggesting sgRNA enrichment [38].

To identify mutations that specifically enhance FTS efficacy, we searched for sgRNAs that were further depleted (with a negative beta score) upon FTS treatment. Gene Ontology (GO) pathway analysis based on false discovery rate (FDR) adjusted $p$-values of less than 0.05 pointed to several pathways in regulating the FTS response, including mitochondrial respiratory chain, protein retrograde transport from ER to cytosol, and proteasome-mediated ubiquitin-dependent protein catabolic processes (Fig. 1b, Supplementary Table 2). In particular, sgRNAs targeting various ERAD-related genes, including Ube2g2, Faf2, Syvn1, Sel1l, Aup1, and Derl2, were significantly depleted from the FTS pool (Fig. 1c-d) $[39,40]$. These molecules are essential components of ERAD, a process responsible for the clearance of misfolded proteins in the ER through cytosolic translocation and proteasomal degradation [41]. Retro-translocation of ERAD substrates across the ER membrane is mediated by the HRD1-SEL1L complex, representing the most conserved ERAD machinery. The E3 ligase HRD1 (encoded by Syvn1) forms a translocation channel while SEL1L functions as the adaptor protein $[42,43]$. A member of Derlin family of proteins, DERL2, is an essential functional partner of HRD1-SEL1L complex [44]. Another ERAD-related protein, AUP1, recruits the E2 ubiquitin-conjugating enzyme UBE2G2 during the ubiquitination of substrates [45]. Following retrotranslocation and polyubiquitination, substrates are extracted from the ER membrane by the AAA ATPase $\mathrm{VCP} / \mathrm{p} 97$ complex and transferred to the cytosolic proteasome for degradation [46, 47]. Another component,
UBXD8 (encoded by Faf2) is an ER membraneembedded recruitment factor for $\mathrm{VCP} / \mathrm{p} 97$ [48]. Thus, our CRISPR screen identifies multiple key components of ERAD, pointing to ERAD as a major pathway affecting the therapeutic efficacy of FTS.

\section{ERAD inhibition synergizes with FTS to activate ER stress and induce apoptosis}

To determine whether inhibition of ERAD could synergize with FTS treatment to induce cell death in PDAC cells, we combined an ERAD inhibitor, Eeyarestatin I (EerI), with FTS. EerI acts through the inhibition of $\mathrm{VCP} / \mathrm{p} 97$, which mediates the translocation of misfolded proteins from ER to cytosol for proteasomal degradation $[49,50]$. We treated three PDAC cell lines (murine 4292, human PANC-1 and MIA PaCa-2) with FTS, EerI, or both for 5 days, and assessed cell survival by microscopic observation and viability assay. While FTS only modestly reduced the viability of PDAC cells, combined treatment with EerI and FTS drastically decreased cell viability (Fig. 2). Berenbaum combination index (CI) [51] showed CI values of less than 1 for all the cell lines, confirming a synergistic effect on combined treatment (Supplementary Fig. S1).

Tumor cells are exposed to intrinsic and environmental factors, such as oncogene activation, hypoxia, glucose deprivation, and lactic acidosis, which perturb protein homeostasis and lead to endoplasmic reticulum (ER) stress. To relieve ER stress and restore proteostasis, tumor cells have adopted a specific stress response pathway, UPR, that includes three main branches initiated by IRE1 $\alpha$, PERK, and ATF6 [52]. The signaling pathways in the three branches cooperate to reduce protein translation and enhance the ER-folding capacity. Additionally, the ERAD pathway is activated to translocate and degrade the misfolded proteins accumulated in the ER. Notably, ERAD and UPR are engaged in a crosstalk, in which, UPR triggers ERAD, while impaired ERAD activates UPR [53]. FTS has been reported to induce ER stress in $M Y C$-amplified cancer cells as indicated by upregulation of UPR markers [54]. Analysis of gene expression profiles in FTS-treated cancer cells points to the upregulation of stress response genes, such as ATF3 and ATF4 [55]. We demonstrated that inhibition of ERAD, a downstream cellular process triggered by UPR, enhanced FTS efficacy, suggesting that FTS likely induces UPR in the KRAS-driven PDAC tumor cells. Therefore, we examined UPR in these PDAC cells. Intriguingly, FTS treatment induced sustained UPR in all three PDAC cell lines, shown by increased levels of phospho-PERK ( $p$ PERK), phospho-eukaryotic translation initiation factor $2 \alpha$ (p-eIF2 $\alpha$ ), and ATF4 (Fig. 3a, Supplementary Fig. S2).

EerI was reported to induce accumulation of misfolded proteins and UPR in cancer cells by blocking ERAD [56] and/or inhibiting Sec61 complex-mediated translocation 


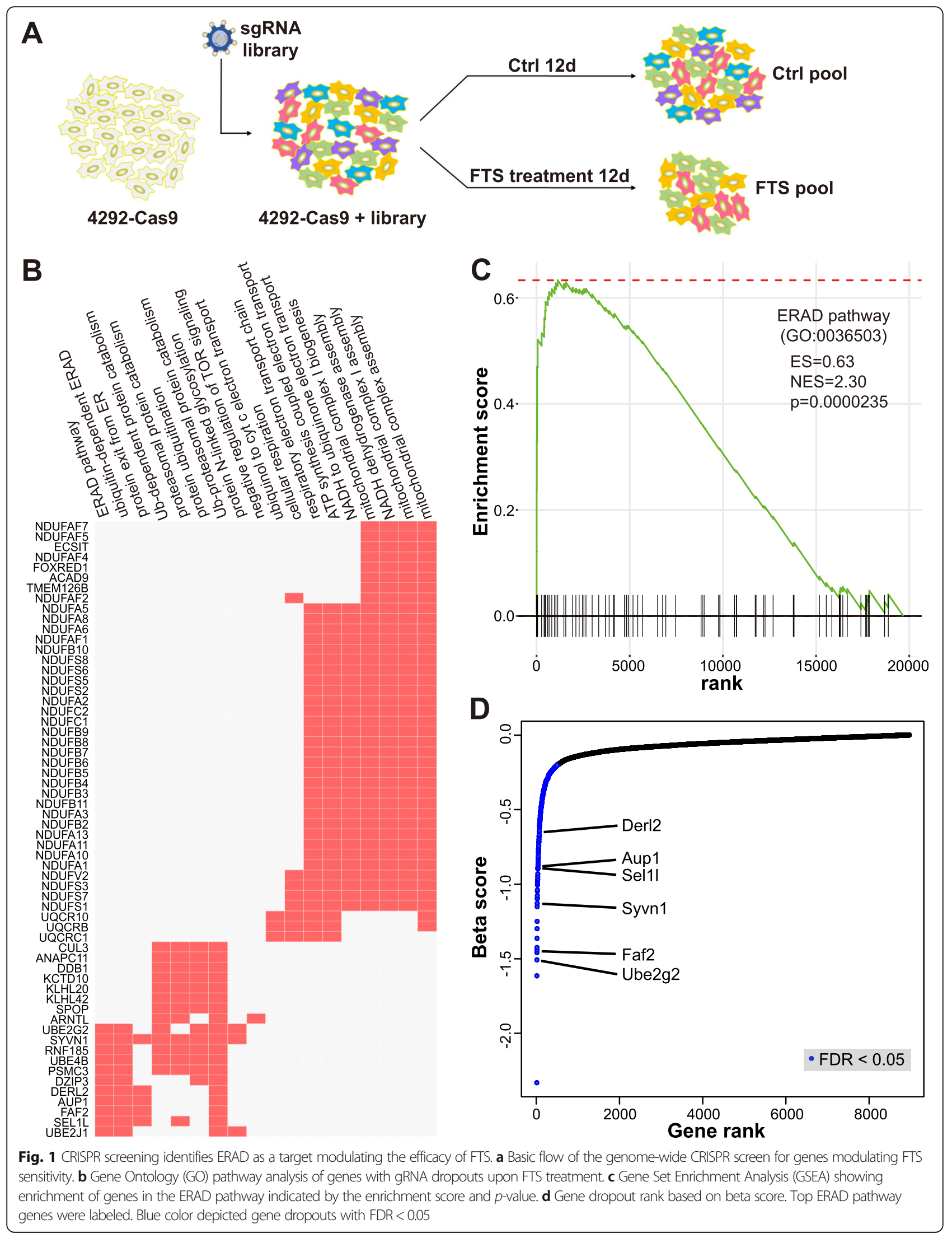



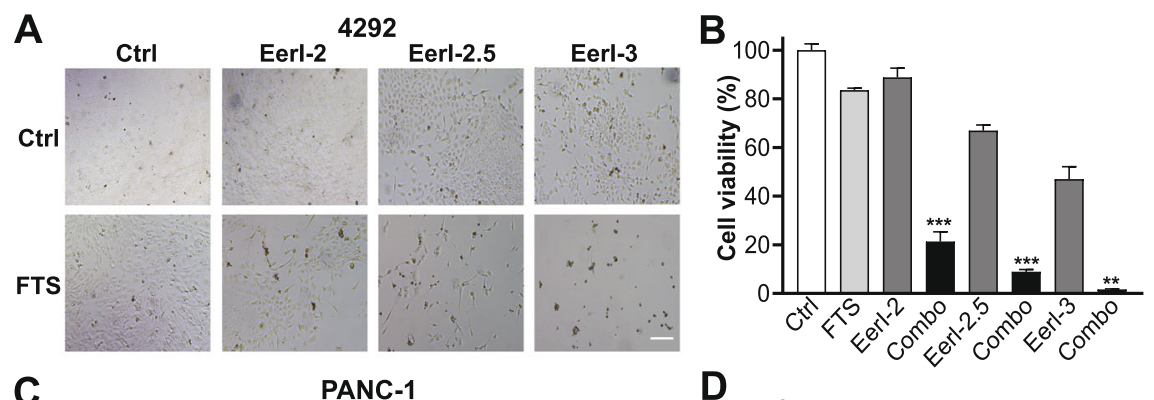

C

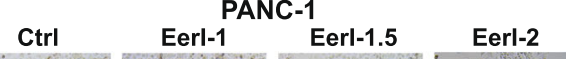

$D$
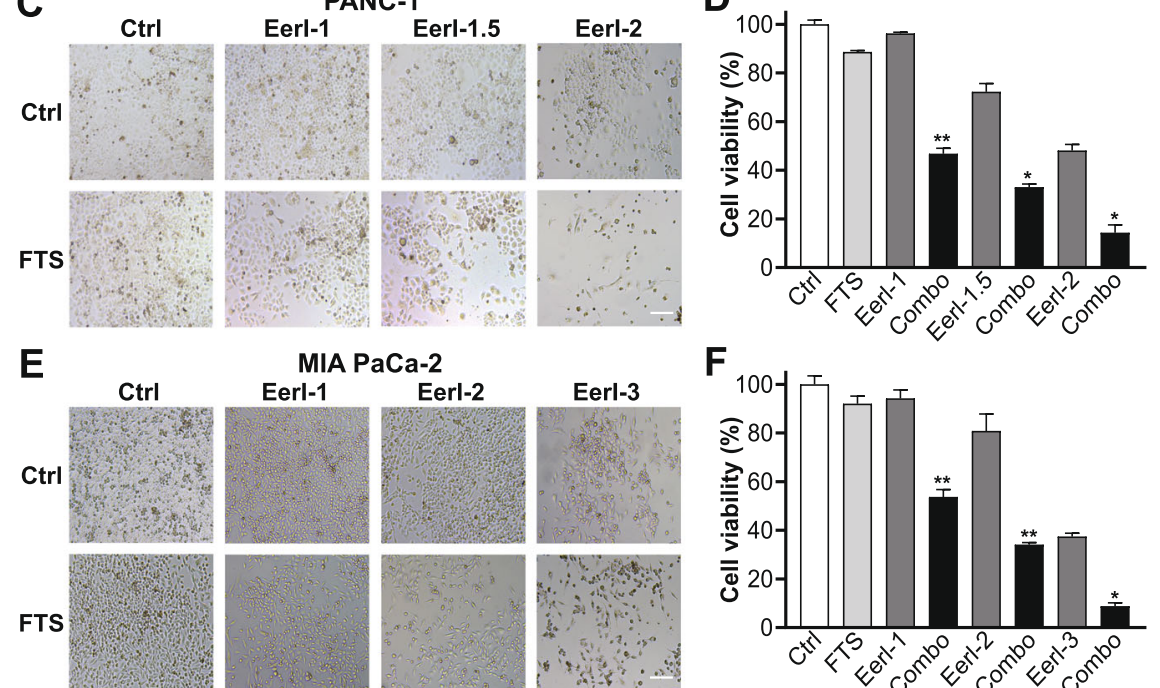

F
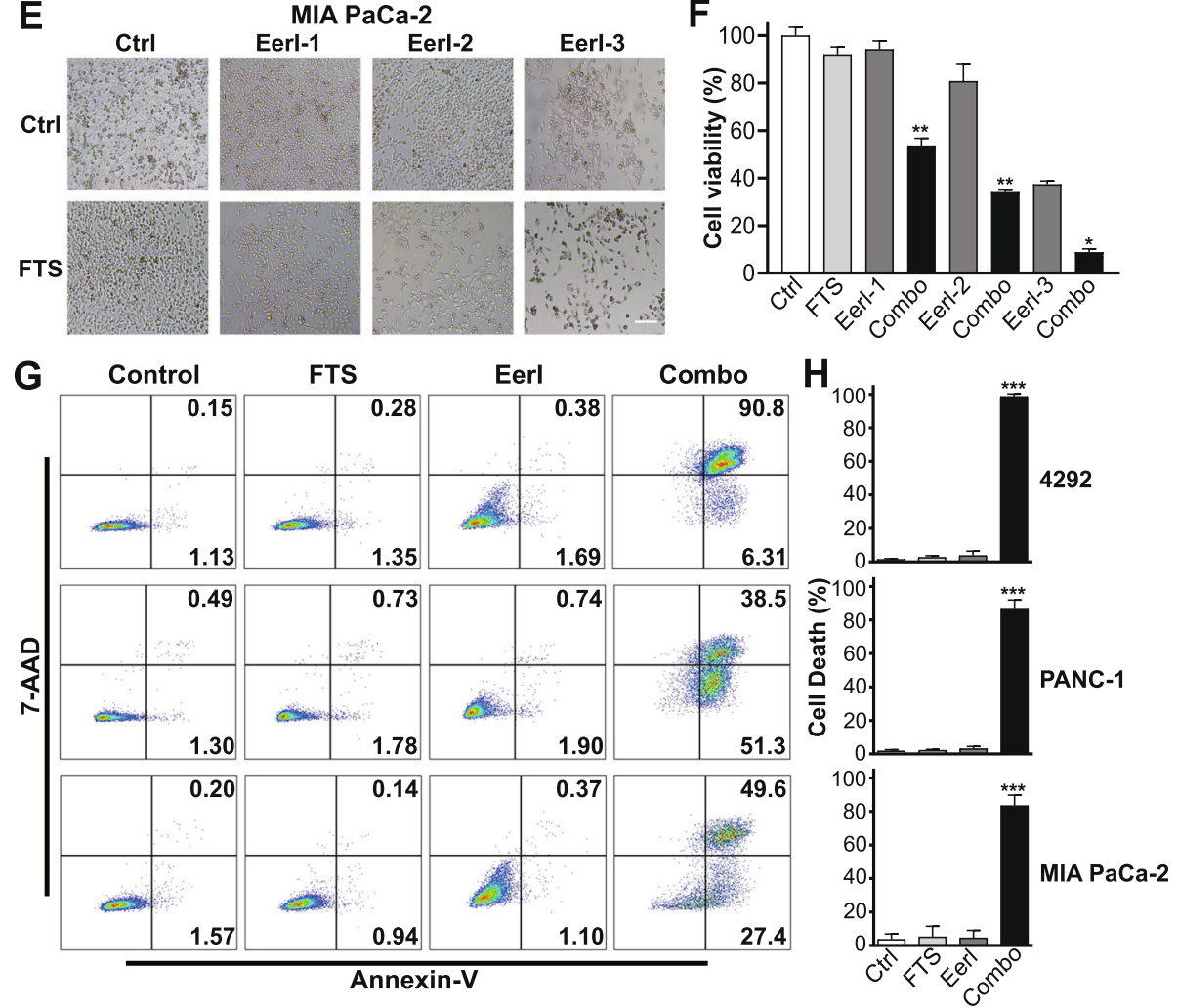

Fig. 2 Eerl synergizes with FTS to kill PDAC cells through apoptosis induction. a, c, e Bright field images (200X) of 4292, PANC-1, and MIA PaCa-2 cells treated with $100 \mu \mathrm{M}$ FTS, Eerl, or both for five days. Eerl $(\mu \mathrm{M})$ concentrations were indicated above each figure. Scale bar, $25 \mu \mathrm{m}$. $\mathbf{b}$, $\mathbf{d}$, $\mathbf{f}$ Relative cell viability following five days of treatment with FTS, Eerl, or both. ANOVA with Tukey's test compares the viability difference between combination and single treatments or controls. ${ }^{*} P<0.05$, ${ }^{*} P<0.01,{ }^{* *} P<0.001$; data are presented as mean \pm SD; $n=3$ ). g Representative flow cytometric analysis of PDAC cell apoptosis following treatments with $100 \mu \mathrm{M}$ FTS, Eerl ( $3 \mu \mathrm{M}$ for $4292,2.5 \mu \mathrm{M}$ for PANC-1 and MIA PaCa-2), or both for five days. Cells were stained with annexin-V and 7-AAD. Percentages of apoptotic cells were indicated in the quadrants. $\mathbf{h}$ PDAC cell death analysis following different treatments with Annexin V/7-AAD apoptosis assay. ANOVA with Tukey's test compares difference treatment groups. ${ }^{* * *} P<0.001$; data presented as mean $\pm \mathrm{SD} ; n=3$. 

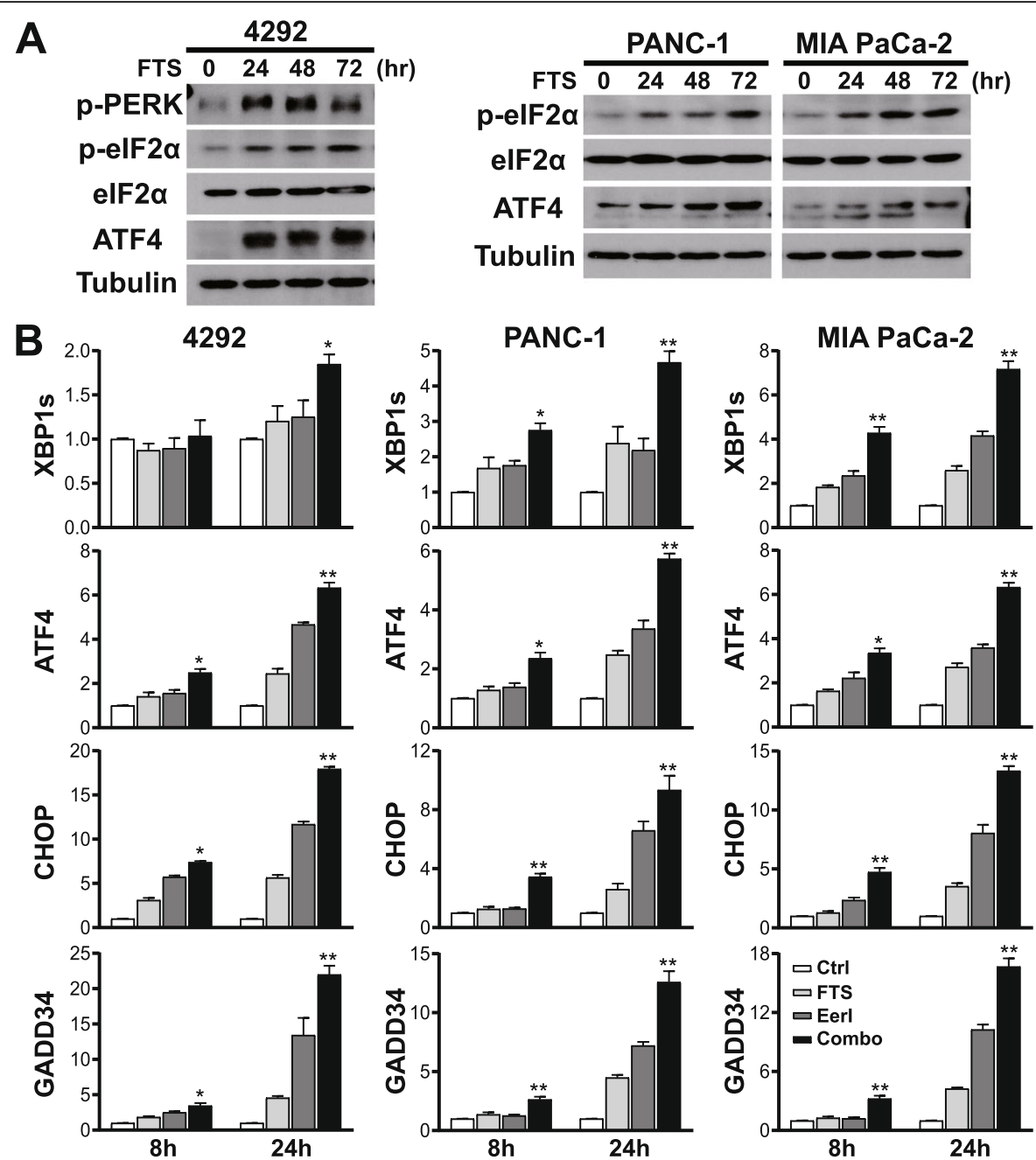

C

PANC-1

MIA PaCa-2

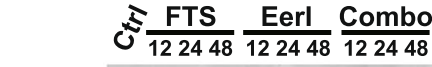

ث $\frac{\text { FTS }}{122448} \frac{\text { Eerl }}{122448} \frac{\text { Combo }}{122448}$

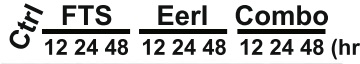

BIM EL

-
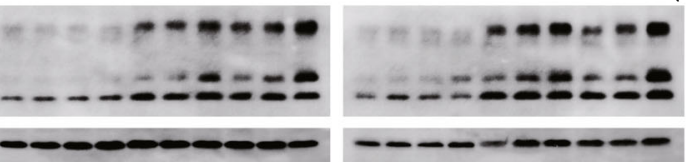

BIM L

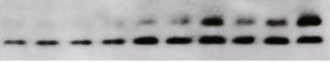

Tubulin - - - - - -

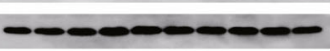

D

4292

PANC-1
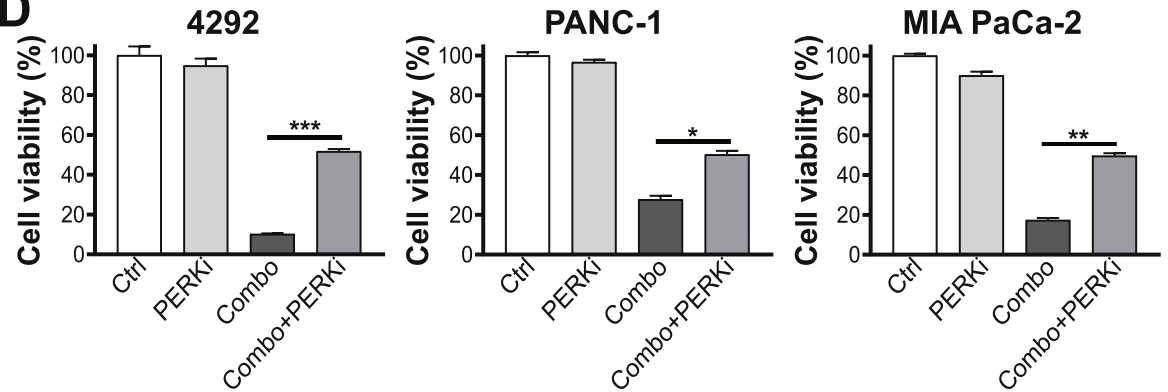

Fig. 3 (See legend on next page.) 
(See figure on previous page.)

Fig. 3 Activation of UPR by FTS is further enhanced upon ERAD inhibition to elicit ER stress-induced apoptosis. a Protein expression of UPR markers (p-PERK, p-elF2a, ATF4) in PDAC cells treated with $100 \mu \mathrm{M}$ FTS for $72 \mathrm{~h}$. $\mathbf{b}$ Changes in transcript levels of UPR marker genes (XBP1s, ATF4, CHOP, and GADD34) following treatment with $100 \mu \mathrm{M}$ FTS, Eerl (3 $\mu \mathrm{M}$ for 4292 and MIA PaCa-2, $2 \mu \mathrm{M}$ for PANC-1), or both for 8 and $24 \mathrm{~h}$. All mRNA values were normalized to human GAPDH or mouse UBC. Two-tailed student's $t$ test compares transcriptional difference between combination and single treatments or control at the same timepoint, ${ }^{*} P<0.05,{ }^{* *} P<0.01$; data presented as mean $\pm S D ; n=3$. c Protein expression of BIM isoforms in PDAC cells in response to treatments with FTS, Eerl, or the combination for $48 \mathrm{~h}$. $\mathbf{d}$ Pretreatment with PERKi $(2.5 \mu \mathrm{M}$ GSK2606414) for two hours partially blocked the cell death induced by the combined FTS and Eerl treatment for five days. Two-tailed student's $\mathrm{t}$ test, ${ }^{*} P<0.05,{ }^{* *} P<0.01,{ }^{* * *} P<0.001$; relative cell viability are presented as mean $\pm S D ; n=3$

of newly synthesized chaperones from cytosol to the ER [57]. To determine the effect of combined FTS-Eer1 treatment on UPR, we examined the mRNA levels of multiple UPR marker genes. Compared to treatment with FTS or EerI alone, combined treatment elicited UPR hyperactivation through IRE1 $\alpha$ and PERK branches, as indicated by the dramatic increase in XBP1s, ATF4, CHOP, and GADD34 transcripts (Fig. 3b) [56, 58]. Notably, ATF4/CHOP signaling, known to induce apoptotic cell death [59-61], was significantly enhanced by the combined treatment.

Current data support proadaptive as well as proapoptotic roles for UPR. Homeostatic UPR signaling may promote tumor progression by supporting tumor cell survival and resistance to chemotherapy and radiation therapy $[62,63]$. However, in cases where ER stress remains overwhelmingly unresolved, activation of a terminal UPR program will lead to cell death [64-66]. Apoptosis following ER stress can be mediated by multiple mechanisms [67-69]. In particular, hyperactivation of the PERK/eIF2 $\alpha / A T F 4$ pathway induces apoptosis through the regulation of proapoptotic transcription factor $\mathrm{CHOP}$ and $\mathrm{Bcl}-2$ family proteins [70-76]. Consistent with the upregulation of ATF4/CHOP upon combined treatment with FTS and EerI, significant apoptosis was observed in murine and human PDAC cell lines as detected by the Annexin V/7-AAD apoptosis assay (Fig. $2 \mathrm{~g}-\mathrm{h}$ ). Thus, we show that combined treatment synergizes to induce apoptosis in PDAC tumor cells. Bcl-2 homology 3 (BH3)-only proapoptotic proteins, such as BIM and NOXA, are regulated by ATF4/CHOP signaling and mediate ER stress-induced apoptosis [56, 73, 77]. Indeed, BIM protein was significantly upregulated upon combination treatment in PDAC cells (Fig. 3c, Supplementary Fig. S2). Pretreatment of PDAC cells with a PERK inhibitor (PERKi), GSK2606414, partially blocked the induction of cell death by the combined treatment (Fig. 3d), suggesting that activation of PERK/eIF2 $\alpha / \mathrm{ATF} 4 / \mathrm{CHOP}$ proapoptotic pathway contributes to the synergistic cell death.

\section{Genetic knockout of SYVN1 and SEL1L sensitizes PDAC cells to FTS treatment}

HRD1-SEL1L complex is an essential component of ERAD pathway. HRD1, encoded by SYVN1 gene, is an E3 ubiquitin ligase involved in processing of misfolded proteins. SEL1L is an HRD1 adaptor protein, and indispensable for ERAD [78]. To demonstrate genetically that inhibition of ERAD indeed enhances the FTS therapeutic efficacy, we knocked out SYVN1 and SEL1L genes in MIA PaCa-2 cells utilizing the CRISPR/Cas9 system. Complete loss of SYVN1 and SEL1L expression was confirmed by Western blot analysis and genomic DNA sequencing (Fig. 4a, Supplementary Fig. S3-4). We tested three individual knockout (KO) clones for each gene (Fig. 4a) and demonstrated that these clones exhibited increased sensitivity to FTS treatment (Fig. 4b). To further examine the drug sensitivity in the knockout clones, we performed a multicolor competition assay (MCA), in which the mCherry-labeled wild type control clone was co-cultured with GFP-labeled SYVN1 KO1 or SEL1L $\mathrm{KO} 1$ clones at a 1:1 ratio, and treated with either vehicle or FTS for 2 weeks [79]. Compared to the non-treated population, the FTS-treated cells showed predominance of mCherry-labeled wild type cells, indicating increased vulnerability of SYVN1 and SEL1L deficient cells (Fig. 4c-d). Thus, PDAC cells with genetic defects in the ERAD machinery are more sensitive to FTS treatment.

In $S Y V N 1$ and SEL1L KO cells, increased sensitivity to FTS coincided with increased level of ER stress. SYVN1 KO1 and SEL1L KO1 cells treated with FTS showed dramatic upregulation of UPR marker genes, including XBP1s, ATF4, CHOP, and GADD34 (Fig. 4e), suggesting that cells with genetic defects in ERAD are more prone to proapoptotic UPR. Furthermore, expression of the pro-apoptotic protein BIM, in particular the BIM L isoform, was strongly induced in these clones following FTS treatment (Fig. 4f, Supplementary Fig. S4), pointing to the induction of apoptosis by the hyperactive ER stress. In summary, using both pharmacological and genetic approaches, we demonstrate that targeting ERAD improves the therapeutic efficacy of FTS through increased activation of ER stress and the subsequent induction of apoptosis (Fig. 5).

\section{Discussion}

Using a genome-wide CRISPR synthetic lethal screen, we have identified ERAD as a key cellular target to enhance FTS efficacy. We show that FTS treatment induces ER stress, which is further amplified by inhibition 


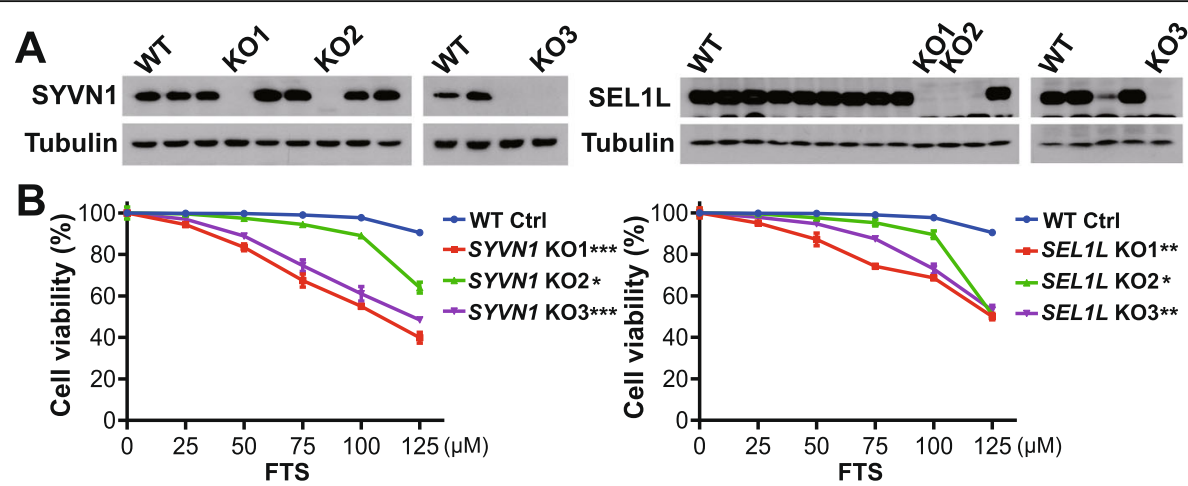

C
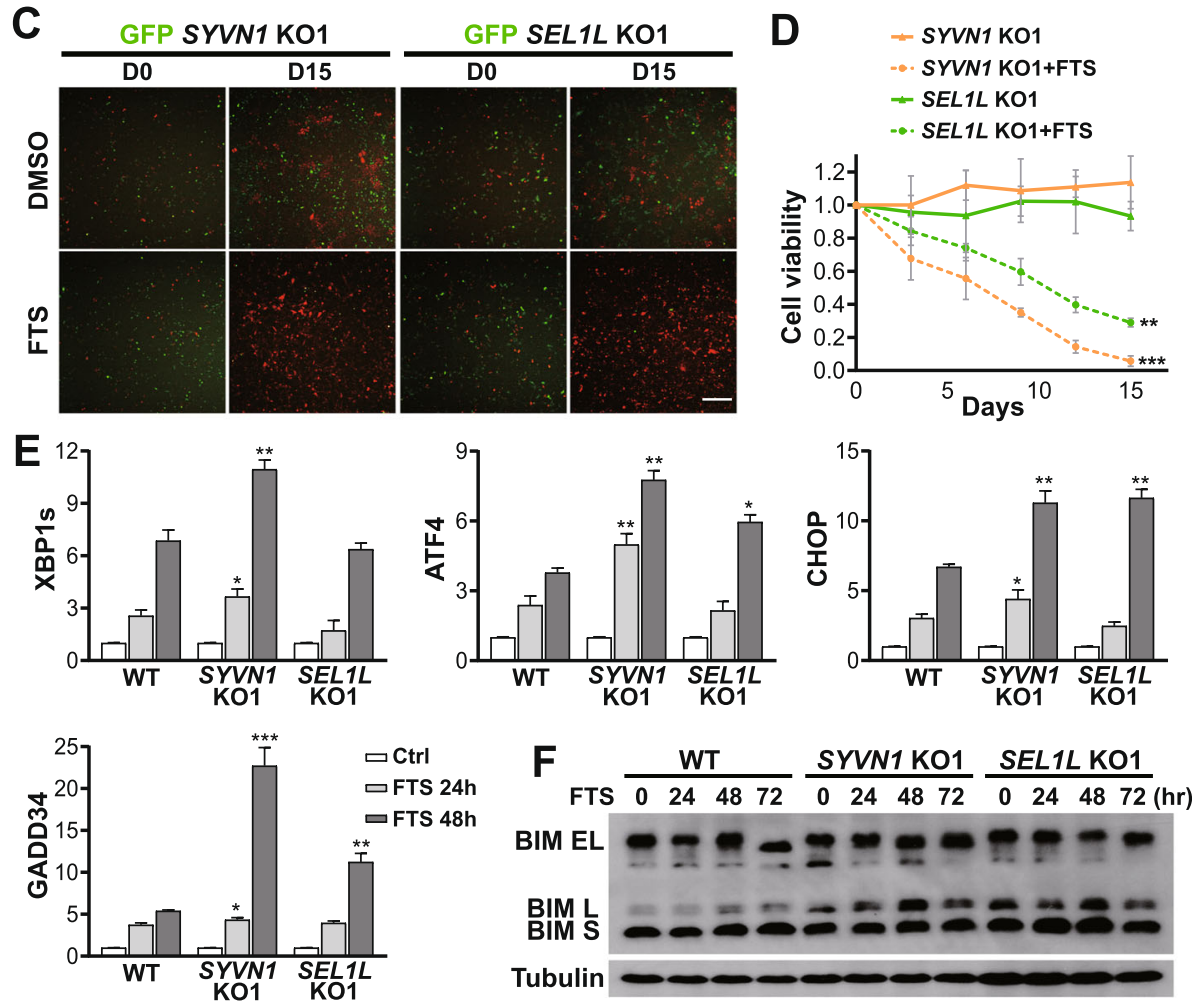

Fig. 4 Knockout of SWN1 and SELIL sensitizes PDAC cells to FTS treatment through proapoptotic UPR. a Validation of SYNN1 and SEL1L CRISPR knockouts by western blot analysis of single clones derived from MIA PaCa-2 cells. b Relative cell viability of wild type control and SWN1 and SEL1L KO clones treated with 25-125 MM FTS for five days. Two-tailed student's t test, ${ }^{*} P<0.05,{ }^{* *} P<0.01,{ }^{* * *} P<0.001$; data are presented as mean \pm SD; $n=3$. $\mathbf{c}$ Representative images of multicolor competition assay (50X) in the presence of $125 \mu \mathrm{M}$ FTS. Scale bar, $100 \mu \mathrm{m}$. d Quantitative analysis of MCA for SWN1 KO1 and SEL1L KO1 cell following FTS treatment. Unpaired two-sample t test, ${ }^{* *} P<0.01,{ }^{* * *} P<0.001$; data are presented as mean $\pm S D ; n=3$. e Changes in transcript levels of UPR markers (XBP1s, ATF4, CHOP, and GADD34) in wild type control, SWN1 KO1 and SEL1L KO1 cells following treatment with $100 \mu \mathrm{MM}$ FTS for $48 \mathrm{~h}$. All mRNA values were normalized to human GAPDH. Two-tailed student's $t$ test compares transcriptional difference between KO clones and WT control at the same timepoint, ${ }^{*} P<0.05$, ${ }^{*} P<0.01,{ }^{* * *} P<0.001$; data are presented as mean $\pm S D ; n=3$. (F) BIM protein expression in wild type control, SWN1 KO1, and SEL1L KO1 cells following treatment with $100 \mu \mathrm{M}$ FTS for $72 \mathrm{~h}$

of ERAD, resulting in synergistic induction of apoptosis in PDAC cells (Fig. 5). In pancreatic cancer, a highly desmoplastic stroma leads to hypoxia and nutrients deprivation [80]. Therefore, pancreatic cancer is more vulnerable to the induction of ER stress. Consequently, therapeutic options that promote ER stress and activate apoptosis may be exploited for PDAC treatment. We have identified one such therapeutic approach by combining FTS and ERAD inhibitors, the efficacy of which, may be examined in vivo for the treatment of PDAC. Similarly, FTS may be combined with other ER stress inducers, such as proteasome inhibitors [81], to generate severe ER stress and tumor cell apoptosis. Combined use of FTS and gemcitabine has been empirically examined for clinical pancreatic cancer treatment [22]. Our study on the mechanisms of drug synergy will provide new options for future PDAC treatments. Recent studies suggest that resolution of ER stress leads to tumor 


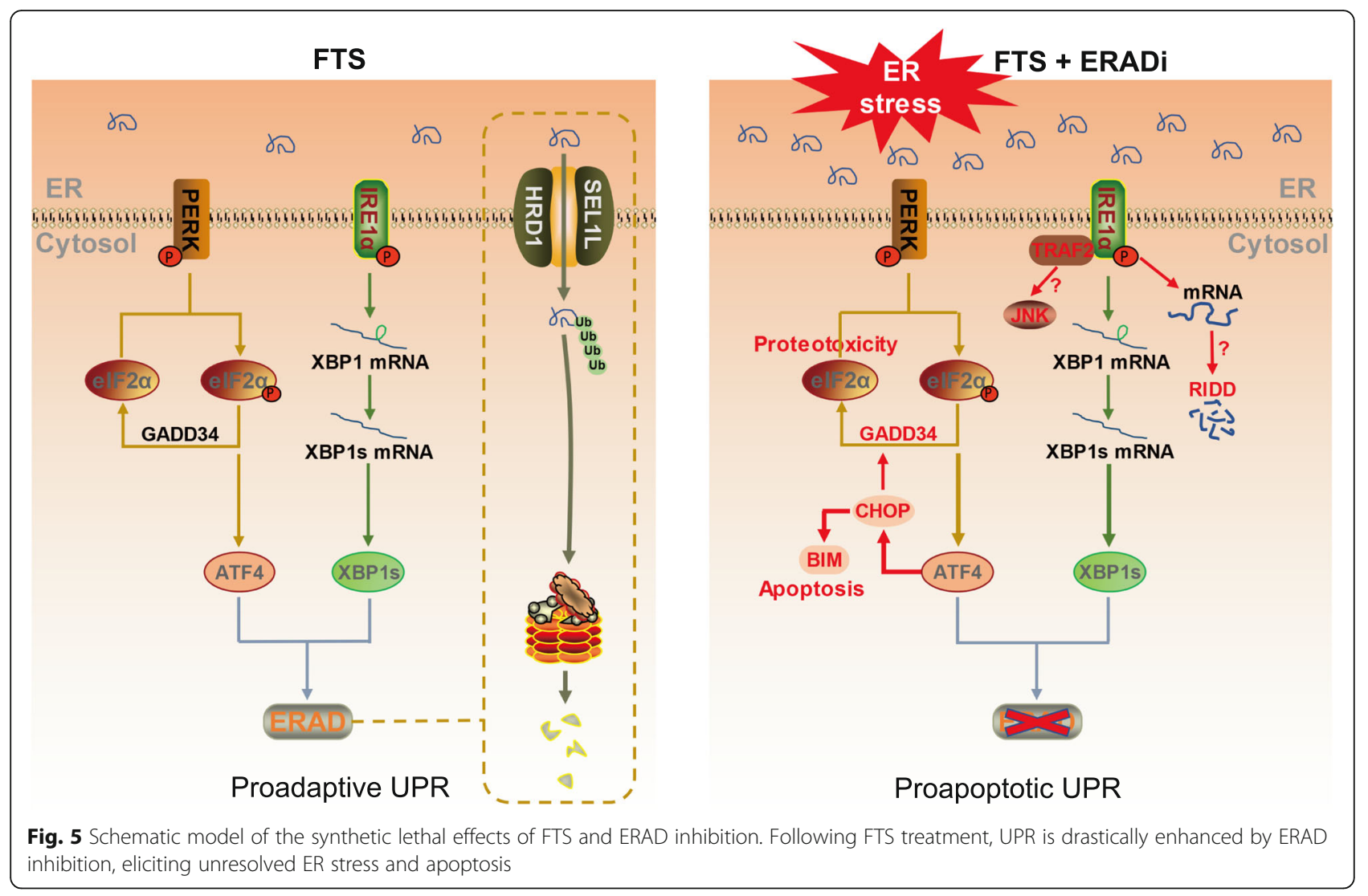

proliferation and formation of metastases from the disseminated PDAC cells [82]. Under constitutive ER stress, metastatic cells may remain dormant and fail to develop overt tumor masses. In this light, the combined use of FTS and ERAD inhibitors, may serve as a novel therapeutic option against metastatic PDAC.

Regulation of tumor cell survival following ER stress is complicated [62, 63, 83]. Our study argues that FTSinduced ER stress is relieved by activation of proadaptive UPR and ERAD, while ERAD inhibition through induction of ER stress, leads to hyperactivation of PERK/eIF $2 \alpha /$ ATF4/CHOP/BIM proapoptotic pathway and massive cell death. Additionally, activation of IRE1 $\alpha$ signaling pathway can recruit TRAF2 and JNK to induce cell death, or contribute to apoptosis through regulation of IRE1-dependent decay (RIDD) [84, 85]. On the other hand, proapoptotic mediators, such as ATF4 and CHOP, have been shown to activate multiple autophagy genes as a pro-survival response to counteract the ER stress [86]. Thus, cell fate control following ER stress may depend on the fine-tuning of UPR, and the crosstalk between UPR, ERAD, autophagy, and apoptosis [53, 87, 88].

Our CRISPR screen has identified additional targets that may enhance the FTS therapeutic efficacy. In a transgenic mouse model of pancreatic cancer, cell survival following KRAS ablation depends on mitochondrial function, especially oxidative phosphorylation [35]. In this regard, our study has identified several genes encoding mitochondria complex I subunits, mitochondria complex II subunits, as well as the mitochondrial iron-sulfur cluster assembly machinery [89-91]. Additionally, we identified Sptlc1, Sptlc2, and Kdsr genes, encoding the serine palmitoyltransferase (SPT) and 3-ketodihydrosphingosine reductase (KDHR), among the top candidates. SPT and KDHR serve as essential enzymes in the initial steps of de novo sphingolipid synthesis [92]. As sphingolipids are structural components of plasma membrane, inhibition of sphingolipid metabolism may mislocalize oncogenic KRAS and abolish its signaling [93]. Our findings suggest that multiple approaches to dislodge KRAS from plasma membrane may be combined to abrogate oncogenic KRAS signaling. Other candidate genetic targets in our screen are involved in apoptosis, mTOR signaling, and fatty acids and selenoprotein metabolism [94, 95]. Further studies will examine the role of these genetic targets in modulating FTS efficacy in the treatment of PDAC.

\section{Conclusion}

Using both genetic and pharmacological approaches, we have demonstrated a critical role for ERAD in enhancing the FTS therapeutic response. The combined use of FTS and ERAD inhibitors may be an effective therapeutic option for the treatment of PDAC. 


\section{Supplementary Information}

The online version contains supplementary material available at https://doi. org/10.1186/s12885-021-07967-6

Additional file 1: Supplementary Fig. S1. Combination indexes show synergistic effect between Eerl and FTS (A) Berenbaum combination index $(\mathrm{Cl})$. Cl value of lower than 1 indicates synergy. (B) Cell viability tests presented as mean \pm SD. Data analysis and calculation of IC50 was performed using GraphPad Prism 8. (C) The CI values of FTS and Eerl in 4292, PANC-1, and MIA PaCa-2 cells, indicating synergistic effect. Supplementary Fig. S2. Original images of the Western blot presented in Fig. 3a and C. Supplementary Fig. S3. Validation of SYVN1 and SEL1L CRISPR knockouts by PCR and Sanger sequencing (A) Map of SYVN1 and SELIL and their respective sgRNAs. Half-arrows indicate the primer sets used to for PCR amplification. Primer sequences are listed in Supplementary Table 5. (B) PCR amplicons of wild type control and the knockouts using primer sets depicted in S3A. (C) Sanger sequencing of SYVN1 exon3 PCR products. In SYVN1 KO1, one allele shows $40 \mathrm{nt}$ deletion between the targeting sites of sg2 and sg3, and mutations/frameshift around sg3 targeting site in the other allele. (D) Sanger sequencing of SEL1L 1F-3R PCR product from SEL1L KO1 validating a 106 nucleotide deletion between the targeting sites of sg1 and sg3. Supplementary Fig. S4. Original images of the Western blot presented in Fig. 4a and $\mathrm{f}$

Additional file 2: Supplementary Table 1. Genes rank based on their beta scores in ascending order from the FTS screen. Supplementary Table 2. GO pathway analysis of top candidate genes from FTS screen. Supplementary Table 3. The sequences of primers used in qPCR assay. Supplementary Table 4. sgRNA oligonucleotide sequences for SYVN1/ SEL1L knockout. Supplementary Table 5. PCR primers used to validate genomic knockout of SYVN1 and SEL1L

\section{Abbreviations}

PDAC: Pancreatic ductal adenocarcinoma; CRISPR: Clusters of regularly interspaced short palindromic repeats; FTS: Farnesyl thiosalicylic acid; Eerl: Eeyarestatin I; UPR: Unfolded protein response; ERAD: Endoplasmic reticulum-associated protein degradation; IC50: Half-maximal inhibitory concentration; qPCR: Quantitative real-time PCR; GFP: Green fluorescent protein; MCA: Multicolor competition assay; GO: Gene Ontology; GSEA: Gene Set Enrichment Analysis; Cl: Combination index; p-elF2a: Phospho-eukaryotic translation initiation factor 2a; p-PERK: Phospho-PERK; PERKi: PERK inhibitor; KO: Knockout; SPT: Serine palmitoyltransferase; KDHR: 3-

ketodihydrosphingosine reductase

\section{Acknowledgments}

The authors greatly appreciate Dr. Marina Pasca di Magliano for generously providing the murine pancreatic cancer cell line (4292).

\section{Authors' contributions}

R.D., N.G.A, and Y.L. developed the study. R.D. performed the molecular and cell biology experiments. N.G.A. carried out the CRISPR FTS synthetic lethal screens. D.K.S. analyzed the CRISPR screening data. R.D. and Y.L. wrote the manuscript. All authors read and approved the final manuscript.

\section{Funding}

This work was supported in part by NIH/NCI K22CA207598 (Y.L.), CPRIT RP200472 (Y.L.), and NIH GM008042 (D.K.S.; UCLA-Caltech Medical Scientist Training Program).

Availability of data and materials

CRISPR screen data is available at GEO accession number GSE162065.

\section{Declarations}

Ethics approval and consent to participate Not applicable.

\section{Consent for publication}

Consent for publication is not needed as no patient data are included in this study.

\section{Competing interests}

The authors declare that they have no competing interests

\section{Author details}

${ }^{1}$ Center for Immunotherapy Research, Houston Methodist Research Institute, Houston, TX 77030, USA. ²Department of Medicine, Weill Cornell Medical College, New York, NY 10065, USA. ${ }^{3}$ Department of Neurosurgery, Xiangya Hospital, Central South University, Changsha 410008, Hunan, China. ${ }^{4}$ UCLA-Caltech Medical Scientist Training Program, David Geffen School of Medicine, University of California, Los Angeles, CA 90095, USA.

Received: 18 November 2020 Accepted: 22 February 2021

Published online: 06 March 2021

\section{References}

1. Kamisawa T, Wood LD, Itoi T, Takaori K. Pancreatic cancer. Lancet. 2016; 388(10039):73-85.

2. Waters AM, Der CJ. KRAS: The Critical Driver and Therapeutic Target for Pancreatic Cancer. Cold Spring Harb Perspect Med. 2018;8(9):a031435.

3. Bos $J$, Rehmann $H$, Wittinghofer A. GEFs and GAPs: critical elements in the control of small G proteins. Cell. 2007;129(5):865-77.

4. Pylayeva-Gupta Y, Grabocka E, Bar-Sagi D. RAS oncogenes: weaving a tumorigenic web. Nat Rev Cancer. 2011;11(11):761-74.

5. Vigil D, Cherfils J, Rossman KL, Der CJ. Ras superfamily GEFs and GAPs: validated and tractable targets for cancer therapy? Nat Rev Cancer. 2010; 10(12):842-57.

6. Cox AD, Fesik SW, Kimmelman AC, Luo J, Der CJ. Drugging the undruggable RAS: Mission possible? Nat Rev Drug Discov. 2014;13(11):828-51.

7. Singh $\mathrm{H}$, Longo DL, Chabner BA. Improving prospects for targeting RAS. J Clin Oncol. 2015:33(31):3650-9.

8. Marín-Ramos NI, Ortega-Gutiérrez S, López-Rodríguez ML. Blocking Ras inhibition as an antitumor strategy. Semin Cancer Biol. 2019;54:91-100.

9. Stephen AG, Esposito D, Bagni RK, McCormick F. Dragging ras back in the ring. Cancer Cell. 2014;25(3):272-81.

10. Ostrem JM, Peters U, Sos ML, Wells JA, Shokat KM. K-Ras(G12C) inhibitors allosterically control GTP affinity and effector interactions. Nature. 2013; 503(7477):548-51.

11. Lim SM, Westover KD, Ficarro SB, Harrison RA, Choi HG, Pacold ME, Carrasco M, Hunter J, Kim ND, Xie T, et al. Therapeutic targeting of oncogenic K-Ras by a covalent catalytic site inhibitor. Angew Chem Int Ed Eng. 2014;53(1): 199-204.

12. Lito $P$, Solomon M, Li LS, Hansen R, Rosen N. Allele-specific inhibitors inactivate mutant KRAS G12C by a trapping mechanism. Science. 2016; 351(6273):604-8.

13. Janes MR, Zhang J, Li LS, Hansen R, Peters U, Guo X, Chen Y, Babbar A, Firdaus SJ, Darjania L, et al. Targeting KRAS Mutant Cancers with a Covalent G12C-Specific Inhibitor. Cell. 2018;172(3):578-589.e517.

14. Canon J, Rex K, Saiki AY, Mohr C, Cooke K, Bagal D, Gaida K, Holt T, Knutson CG, Koppada N, et al. The clinical KRAS(G12C) inhibitor AMG 510 drives antitumour immunity. Nature. 2019;575(7781):217-23.

15. Ahearn I, Zhou M, Philips MR. Posttranslational Modifications of RAS Proteins. Cold Spring Harb Perspect Med. 2018;8(11):a031484.

16. Wang M, Casey PJ. Protein prenylation: unique fats make their mark on biology. Nat Rev Mol Cell Biol. 2016;17(2):110-22.

17. Marom M, Haklai R, Ben-Baruch G, Marciano D, Egozi Y, Kloog Y. Selective inhibition of Ras-dependent cell growth by farnesylthiosalisylic acid. J Biol Chem. 1995;270(38):22263-70.

18. Rotblat B, Ehrlich M, Haklai R, Kloog Y. The Ras inhibitor farnesylthiosalicylic acid (Salirasib) disrupts the spatiotemporal localization of active Ras: a potential treatment for cancer. Methods Enzymol. 2008;439:467-89.

19. Zundelevich A, Elad-Sfadia G, Haklai R, Kloog Y. Suppression of lung cancer tumor growth in a nude mouse model by the Ras inhibitor salirasib (farnesylthiosalicylic acid). Mol Cancer Ther. 2007;6(6):1765-73.

20. Haklai R, Elad-Sfadia G, Egozi Y, Kloog Y. Orally administered FTS (salirasib) inhibits human pancreatic tumor growth in nude mice. Cancer Chemother Pharmacol. 2008;61(1):89-96.

21. Riely GJ, Johnson ML, Medina C, Rizvi NA, Miller VA, Kris MG, Pietanza MC, Azzoli CG, Krug LM, Pao W, et al. A phase II trial of Salirasib in patients with lung adenocarcinomas with KRAS mutations. J Thorac Oncol. 2011;6(8): 1435-7. 
22. Laheru D, Shah P, Rajeshkumar NV, McAllister F, Taylor G, Goldsweig H, Le DT, Donehower $\mathrm{R}$, Jimeno A, Linden $\mathrm{S}$, et al. Integrated preclinical and clinical development of S-trans, trans-Farnesylthiosalicylic acid (FTS, Salirasib) in pancreatic cancer. Investig New Drugs. 2012;30(6):2391-9.

23. Badar T, Cortes JE, Ravandi F, O'Brien S, Verstovsek S, Garcia-Manero G, Kantarjian H, Borthakur G. Phase I study of S-trans, trans-farnesylthiosalicylic acid (salirasib), a novel oral RAS inhibitor in patients with refractory hematologic malignancies. Clin Lymphoma Myeloma Leuk. 2015;15(7):433438.e432.

24. Viale A, Pettazzoni P, Lyssiotis CA, Ying H, Sánchez N, Marchesini M, Carugo A Green T, Seth S, Giuliani V, et al. Oncogene ablation-resistant pancreatic cancer cells depend on mitochondrial function. Nature. 2014;514(7524):628-32.

25. Bryant KL, Stalnecker CA, Zeitouni D, Klomp JE, Peng S, Tikunov AP, Gunda V, Pierobon M, Waters AM, George SD, et al. Combination of ERK and autophagy inhibition as a treatment approach for pancreatic cancer. Nat Med. 2019;25(4):628-40.

26. Kaelin WG Jr. The concept of synthetic lethality in the context of anticancer therapy. Nat Rev Cancer. 2005;5(9):689-98.

27. Topatana W, Juengpanich S, Li S, Cao J, Hu J, Lee J, Suliyanto K, Ma D, Zhang B, Chen M, et al. Advances in synthetic lethality for cancer therapy: cellular mechanism and clinical translation. J Hematol Oncol. 2020;13(1):118.

28. Chan SM, Thomas D, Corces-Zimmerman MR, Xavy S, Rastogi S, Hong WJ, Zhao F, Medeiros BC, Tyvoll DA, Majeti R. Isocitrate dehydrogenase 1 and 2 mutations induce BCL-2 dependence in acute myeloid leukemia. Nat Med. 2015;21(2):178-84.

29. Wang C, Jin H, Gao D, Lieftink C, Evers B, Jin G, Xue Z, Wang L, Beijersbergen RL, Qin W, et al. Phospho-ERK is a biomarker of response to a synthetic lethal drug combination of sorafenib and MEK inhibition in liver cancer. J Hepatol. 2018;69(5):1057-65.

30. Shalem O, Sanjana NE, Hartenian E, Shi X, Scott DA, Mikkelson T, Heckl D, Ebert BL, Root DE, Doench JG, et al. Genome-scale CRISPR-Cas9 knockout screening in human cells. Science. 2014;343(6166):84-7.

31. Evers B, Jastrzebski K, Heijmans JP, Grernrum W, Beijersbergen RL, Bernards R. CRISPR knockout screening outperforms shRNA and CRISPRi in identifying essential genes. Nat Biotechnol. 2016;34(6):631-3.

32. Collins MA, Bednar F, Zhang Y, Brisset JC, Galbán S, Galbán CJ, Rakshit S, Flannagan KS, Adsay NV, Pasca di Magliano M. Oncogenic Kras is required for both the initiation and maintenance of pancreatic cancer in mice. J Clin Invest. 2012;122(2):639-53.

33. Collins MA, Brisset JC, Zhang Y, Bednar F, Pierre J, Heist KA, Galbán CJ, Galbán S, di Magliano MP. Metastatic pancreatic cancer is dependent on oncogenic Kras in mice. PLoS One. 2012;7(12):e49707.

34. Joung J, Konermann S, Gootenberg JS, Abudayyeh OO, Platt RJ, Brigham MD, Sanjana NE, Zhang F. Genome-scale CRISPR-Cas9 knockout and transcriptional activation screening. Nat Protoc. 2017;12(4):828-63.

35. Kuleshov MV, Jones MR, Rouillard AD, Fernandez NF, Duan Q, Wang Z, Koplev S, Jenkins SL, Jagodnik KM, Lachmann A, et al. Enrichr: a comprehensive gene set enrichment analysis web server 2016 update. Nucleic Acids Res. 2016;44(W1):W90-7.

36. Liu Y, Azizian NG, Dou Y, Pham LV, Li Y. Simultaneous targeting of XPO1 and BCL2 as an effective treatment strategy for double-hit lymphoma. J Hematol Oncol. 2019;12(1):119.

37. Doench JG, Fusi N, Sullender M, Hegde M, Vaimberg EW, Donovan KF, Smith I, Tothova Z, Wilen C, Orchard R, et al. Optimized sgRNA design to maximize activity and minimize off-target effects of CRISPR-Cas9. Nat Biotechnol. 2016;34(2):184-91.

38. Li W, Köster J, Xu H, Chen CH, Xiao T, Liu JS, Brown M, Liu XS. Quality control, modeling, and visualization of CRISPR screens with MAGeCK-VISPR Genome Biol. 2015;16:281.

39. Christianson JC, Olzmann JA, Shaler TA, Sowa ME, Bennett EJ, Richter CM, Tyler RE, Greenblatt EJ, Harper JW, Kopito RR. Defining human ERAD networks through an integrative mapping strategy. Nat Cell Biol. 2011;14(1): 93-105.

40. Leto DE, Morgens DW, Zhang L, Walczak CP, Elias JE, Bassik MC, Kopito RR. Genome-wide CRISPR Analysis Identifies Substrate-Specific Conjugation Modules in ER-Associated Degradation. Mol Cell. 2019;73(2):377-389.e311.

41. Berner N, Reutter KR, Wolf DH. Protein quality control of the endoplasmic reticulum and ubiquitin-proteasome-triggered degradation of aberrant proteins: yeast pioneers the path. Annu Rev Biochem. 2018;87:751-82.

42. Kikkert M, Doolman R, Dai M, Avner R, Hassink G, van Voorden S, Thanedar S, Roitelman J, Chau V, Wiertz E. Human HRD1 is an E3 ubiquitin ligase involved in degradation of proteins from the endoplasmic reticulum. J Biol Chem. 2004;279(5):3525-34.

43. Vasic V, Denkert N, Schmidt CC, Riedel D, Stein A, Meinecke M. Hrd1 forms the retrotranslocation pore regulated by auto-ubiquitination and binding of misfolded proteins. Nat Cell Biol. 2020;22(3):274-81.

44. Huang $\mathrm{CH}$, Hsiao HT, Chu YR, Ye Y, Chen X. Derlin2 protein facilitates HRD1mediated retro-translocation of sonic hedgehog at the endoplasmic reticulum. J Biol Chem. 2013;288(35):25330-9.

45. Klemm EJ, Spooner E, Ploegh HL. Dual role of ancient ubiquitous protein 1 (AUP1) in lipid droplet accumulation and endoplasmic reticulum (ER) protein quality control. J Biol Chem. 2011;286(43):37602-14.

46. Qi L, Tsai B, Arvan P. New insights into the physiological role of endoplasmic reticulum-associated degradation. Trends Cell Biol. 2017;27(6): 430-40.

47. Wu X, Rapoport TA. Mechanistic insights into ER-associated protein degradation. Curr Opin Cell Biol. 2018;53:22-8.

48. Schuberth $C$, Buchberger A. UBX domain proteins: major regulators of the AAA ATPase Cdc48/p97. Cell Mol Life Sci. 2008;65(15):2360-71.

49. Wang Q, Li L, Ye Y. Inhibition of p97-dependent protein degradation by Eeyarestatin I. J Biol Chem. 2008;283(12):7445-54.

50. Wang Q, Shinkre BA, Lee JG, Weniger MA, Liu Y, Chen W, Wiestner A, Trenkle WC, Ye Y. The ERAD inhibitor Eeyarestatin I is a bifunctional compound with a membrane-binding domain and a p97NCP inhibitory group. PLoS One. 2010;5(11):e15479.

51. Menachem A, Bodner O, Pastor J, Raz A, Kloog Y. Inhibition of malignant thyroid carcinoma cell proliferation by Ras and galectin-3 inhibitors. Cell Death Dis. 2015;1:15047.

52. Karagöz GE, Acosta-Alvear D, Walter P. The Unfolded Protein Response: Detecting and Responding to Fluctuations in the Protein-Folding Capacity of the Endoplasmic Reticulum. Cold Spring Harb Perspect Biol. 2019;11(9): a033886.

53. Hwang J, Qi L. Quality control in the endoplasmic reticulum: crosstalk between ERAD and UPR pathways. Trends Biochem Sci. 2018;43(8):593-605.

54. Yaari-Stark S, Shaked M, Nevo-Caspi Y, Jacob-Hircsh J, Shamir R, Rechavi G, Kloog Y. Ras inhibits endoplasmic reticulum stress in human cancer cells with amplified Myc. Int J Cancer. 2010;126(10):2268-81.

55. Blum R, Elkon R, Yaari S, Zundelevich A, Jacob-Hirsch J, Rechavi G, Shamir R, Kloog Y. Gene expression signature of human cancer cell lines treated with the ras inhibitor salirasib (S-farnesylthiosalicylic acid). Cancer Res. 2007;67(7): 3320-8.

56. Wang $\mathrm{Q}$, Mora-Jensen $\mathrm{H}$, Weniger MA, Perez-Galan P, Wolford C, Hai T, Ron D, Chen W, Trenkle W, Wiestner A, et al. ERAD inhibitors integrate ER stress with an epigenetic mechanism to activate $\mathrm{BH}$-only protein NOXA in cancer cells. Proc Natl Acad Sci U S A. 2009;106(7):2200-5.

57. Cross BC, McKibbin C, Callan AC, Roboti P, Piacenti M, Rabu C, Wilson CM, Whitehead R, Flitsch SL, Pool MR, et al. Eeyarestatin I inhibits Sec61mediated protein translocation at the endoplasmic reticulum. J Cell Sci. 2009;122(Pt 23):4393-400.

58. Ron D, Walter P. Signal integration in the endoplasmic reticulum unfolded protein response. Nat Rev Mol Cell Biol. 2007;8(7):519-29.

59. Han J, Back SH, Hur J, Lin YH, Gildersleeve R, Shan J, Yuan CL, Krokowski D, Wang S, Hatzoglou M, et al. ER-stress-induced transcriptional regulation increases protein synthesis leading to cell death. Nat Cell Biol. 2013;15(5): 481-90.

60. Hetz C, Papa FR. The unfolded protein response and cell fate control. Mol Cell. 2018;69(2):169-81.

61. Almanza A, Carlesso A, Chintha C, Creedican S, Doultsinos D, Leuzzi B, Luís A, McCarthy N, Montibeller L, More $S$, et al. Endoplasmic reticulum stress signalling - from basic mechanisms to clinical applications. FEBS J. 2019; 286(2):241-78.

62. Urra H, Dufey E, Avril T, Chevet E, Hetz C. Endoplasmic reticulum stress and the hallmarks of Cancer. Trends Cancer. 2016;2(5):252-62.

63. Cubillos-Ruiz JR, Bettigole SE, Glimcher LH. Tumorigenic and immunosuppressive effects of endoplasmic reticulum stress in Cancer. Cell. 2017;168(4):692-706.

64. Oakes SA. Endoplasmic reticulum stress signaling in Cancer cells. Am J Pathol. 2020;190(5):934-46.

65. Hetz $C$. The unfolded protein response: controlling cell fate decisions under ER stress and beyond. Nat Rev Mol Cell Biol. 2012;13(2):89-102.

66. Urra H, Dufey E, Lisbona F, Rojas-Rivera D, Hetz C. When ER stress reaches a dead end. Biochim Biophys Acta. 2013;1833(12):3507-17. 
67. Sano R, Reed JC. ER stress-induced cell death mechanisms. Biochim Biophys Acta. 2013;1833(12):3460-70.

68. Tabas I, Ron D. Integrating the mechanisms of apoptosis induced by endoplasmic reticulum stress. Nat Cell Biol. 2011;13(3):184-90.

69. Iurlaro R, Muñoz-Pinedo C. Cell death induced by endoplasmic reticulum stress. FEBS J. 2016;283(14):2640-52

70. McCullough KD, Martindale JL, Klotz LO, Aw TY, Holbrook NJ. Gadd153 sensitizes cells to endoplasmic reticulum stress by down-regulating $\mathrm{Bcl} 2$ and perturbing the cellular redox state. Mol Cell Biol. 2001;21(4):1249-59.

71. Oyadomari S, Mori M. Roles of CHOP/GADD153 in endoplasmic reticulum stress. Cell Death Differ. 2004;11(4):381-9.

72. Li G, Mongillo M, Chin KT, Harding H, Ron D, Marks AR, Tabas I. Role of ERO1-alpha-mediated stimulation of inositol 1,4,5-triphosphate receptor activity in endoplasmic reticulum stress-induced apoptosis. J Cell Biol. 2009; 186(6):783-92.

73. Puthalakath H, O'Reilly LA, Gunn P, Lee L, Kelly PN, Huntington ND, Hughes PD, Michalak EM, McKimm-Breschkin J, Motoyama N, et al. ER stress triggers apoptosis by activating BH3-only protein Bim. Cell. 2007;129(7):1337-49.

74. Marciniak SJ, Yun CY, Oyadomari S, Novoa I, Zhang Y, Jungreis R, Nagata K, Harding HP, Ron D. CHOP induces death by promoting protein synthesis and oxidation in the stressed endoplasmic reticulum. Genes Dev. 2004; 18(24):3066-77.

75. Yamaguchi H, Wang HG. CHOP is involved in endoplasmic reticulum stressinduced apoptosis by enhancing DR5 expression in human carcinoma cells. J Biol Chem. 2004;279(44):45495-502.

76. Ohoka N, Yoshii S, Hattori T, Onozaki K, Hayashi H. TRB3, a novel ER stressinducible gene, is induced via ATF4-CHOP pathway and is involved in cell death. EMBO J. 2005;24(6):1243-55.

77. Pihán P, Carreras-Sureda A, Hetz C. BCL-2 family: integrating stress responses at the ER to control cell demise. Cell Death Differ. 2017;24(9):1478-87.

78. Sun S, Shi G, Han X, Francisco AB, Ji Y, Mendonça N, Liu X, Locasale JW, Simpson KW, Duhamel GE, et al. Sel1 L is indispensable for mammalian endoplasmic reticulum-associated degradation, endoplasmic reticulum homeostasis, and survival. Proc Natl Acad Sci U S A. 2014;111(5):E582-91.

79. MacLeod G, Bozek DA, Rajakulendran N, Monteiro V, Ahmadi M, Steinhart Z, Kushida MM, Yu H, Coutinho FJ, Cavalli FMG, et al. Genome-Wide CRISPRCas9 Screens Expose Genetic Vulnerabilities and Mechanisms of Temozolomide Sensitivity in Glioblastoma Stem Cells. Cell Rep. 2019;27(3): 971-986.e979.

80. Neesse A, Michl P, Frese KK, Feig C, Cook N, Jacobetz MA, Lolkema MP, Buchholz M, Olive KP, Gress TM, et al. Stromal biology and therapy in pancreatic cancer. Gut. 2011;60(6):861-8.

81. Lamothe B, Wierda WG, Keating MJ, Gandhi V. Carfilzomib triggers cell death in chronic lymphocytic leukemia by inducing Proapoptotic and endoplasmic reticulum stress responses. Clin Cancer Res. 2016;22(18):4712-26.

82. Pommier A, Anaparthy N, Memos N, Kelley ZL, Gouronnec A, Yan R, Auffray C, Albrengues J, Egeblad M, lacobuzio-Donahue CA, et al. Unresolved endoplasmic reticulum stress engenders immune-resistant, latent pancreatic cancer metastases. Science (New York, NY). 2018:360(6394):eaao4908.

83. Wang M, Kaufman RJ. The impact of the endoplasmic reticulum proteinfolding environment on cancer development. Nat Rev Cancer. 2014;14(9): $581-97$.

84. Han D, Lerner AG, Vande Walle L, Upton JP, Xu W, Hagen A, Backes BJ, Oakes SA, Papa FR. IRE1alpha kinase activation modes control alternate endoribonuclease outputs to determine divergent cell fates. Cell. 2009; 138(3):562-75.

85. Urano F, Wang X, Bertolotti A, Zhang Y, Chung P, Harding HP, Ron D. Coupling of stress in the ER to activation of JNK protein kinases by transmembrane protein kinase IRE1. Science. 2000;287(5453):664-6.

86. B'Chir W, Maurin AC, Carraro V, Averous J, Jousse C, Muranishi Y, Parry L, Stepien G, Fafournoux P, Bruhat A. The elF2a/ATF4 pathway is essential for stress-induced autophagy gene expression. Nucleic Acids Res. 2013;41(16): 7683-99.

87. Senft D, Ronai ZA. UPR, autophagy, and mitochondria crosstalk underlies the ER stress response. Trends Biochem Sci. 2015;40(3):141-8.

88. Bhardwaj M, Leli NM, Koumenis C, Amaravadi RK. Regulation of autophagy by canonical and non-canonical ER stress responses. Semin Cancer Biol. 2020;66:116-28

89. Sharma LK, Lu J, Bai Y. Mitochondrial respiratory complex I: structure, function and implication in human diseases. Curr Med Chem. 2009;16(10): 1266-77.
90. Kluckova K, Bezawork-Geleta A, Rohlena J, Dong L, Neuzil J. Mitochondrial complex II, a novel target for anti-cancer agents. Biochim Biophys Acta. 2013;1827(5):552-64

91. Sheftel AD, Wilbrecht C, Stehling O, Niggemeyer B, Elsässer HP, Mühlenhoff $\mathrm{U}$, Lill R. The human mitochondrial ISCA1, ISCA2, and IBA57 proteins are required for [4Fe-4S] protein maturation. Mol Biol Cell. 2012;23(7):1157-66.

92. Gault CR, Obeid LM, Hannun YA. An overview of sphingolipid metabolism: from synthesis to breakdown. Adv Exp Med Biol. 2010;688:1-23.

93. van der Hoeven D, Cho KJ, Zhou Y, Ma X, Chen W, Naji A, Montufar-Solis D, Zuo Y, Kovar SE, Levental KR, et al. Sphingomyelin Metabolism Is a Regulator of K-Ras Function. Mol Cell Biol. 2018;38(3):e00373-17.

94. Yoo MH, Xu XM, Carlson BA, Gladyshev VN, Hatfield DL. Thioredoxin reductase 1 deficiency reverses tumor phenotype and tumorigenicity of lung carcinoma cells. J Biol Chem. 2006;281(19):13005-8.

95. Padanad MS, Konstantinidou G, Venkateswaran N, Melegari M, Rindhe S, Mitsche M, Yang C, Batten K, Huffman KE, Liu J, et al. Fatty acid oxidation mediated by acyl-COA Synthetase long chain 3 is required for mutant KRAS lung tumorigenesis. Cell Rep. 2016;16(6):1614-28.

\section{Publisher's Note}

Springer Nature remains neutral with regard to jurisdictional claims in published maps and institutional affiliations.
Ready to submit your research? Choose BMC and benefit from:

- fast, convenient online submission

- thorough peer review by experienced researchers in your field

- rapid publication on acceptance

- support for research data, including large and complex data types

- gold Open Access which fosters wider collaboration and increased citations

- maximum visibility for your research: over $100 \mathrm{M}$ website views per year

At BMC, research is always in progress.

Learn more biomedcentral.com/submissions 